\title{
THE NIGERIAN SUPREME COURT AND THE POLITICAL QUESTION DOCTRINE
}

\author{
Ekokoi Solomon $^{*} \quad$ Ekereobong Essien ${ }^{* *}$
}

\begin{abstract}
This paper examines the attitude of the Supreme Court of Nigeria towards the political question doctrine. It examines the decisions of the Court in some landmark cases involving political questions since the First Republic up until the Fourth Republic, which commenced in May 1999. The paper identifies three core doctrines espoused by the Court in cases involving political questions: deference, necessity or exigency and avoidance or passive doctrines. This paper demonstrates the inevitability of the Court's engagement in the adjudication of cases involving political questions. This is because by virtue of its role in the governance process, the apex court is both a political and legal institution. The paper, therefore, recommends that the Court should openly assert the 'politicality' of its decisions, whether they are predicated on the Court's deference to the political branches of government, the necessity or exigency of the issues involved in the case at hand, and/or the need to avoid the political question involved in the case before it.
\end{abstract}

\section{INTRODUCTION}

Analyses of decisions of courts in cases which involve political questions are bound to raise the issue of institutional dialogue. The theory of institutional dialogue has been described as the engagement of the courts and legislature in a dialogue 'regarding the determination of the proper balance between constitutional principles and public policies'. ${ }^{1}$ When dialogue occurs between courts and the legislature, both institutions place emphasis on different values. While courts emphasise the need to maintain fundamental procedural values, the legislature, on its part, concerns itself with promoting certain economic, social and political

* Ekokoi Solomon is a PhD candidate at the Faculty of Law, University of Calabar, Nigeria, and Lecturer in Law, Department of Public Law, Faculty of Law, University of Uyo, Nigeria. E-mail: emmanuelsolomon@uniuyo.edu.ng; ekokoisolomon@yahoo.com

** LLB (Hons), BL \& LLM student at the Faculty of Law, Rivers State University, Port Harcourt, Nigeria. E-mail: ekyice1@gmail.com

${ }^{1}$ L Tremblay, 'The Legitimacy of Judicial Review: The Limits of Dialogue between Courts and Legislatures' (2005) 3(4) International Journal of Constitutional Law 617. 


\section{THE NIGERIAN SUPREME COURT AND THE POLITICAL QUESTION DOCTRINE}

ends. ${ }^{2}$ Institutional dialogue sometimes produces conflict between legality and legitimacy. When the decision of a court appears to conflict or actually conflicts with legislative intent or outcome, the former "can be reversed, modified, or avoided by a new law, [and] any concern about the legitimacy of judicial review is greatly diminished'. ${ }^{3}$ This is because the core substance of any new law will have to effectively address the consequence of the court's decision. ${ }^{4}$

In a constitutional democracy, political questions are generally within the realm of the political branches of government (the legislature and executive). In Nigeria, the notion whether judicial self-restrain in cases involving political questions is a myth or reality, is arguably an issue for legal and scholarly debate. The divergent views on the issue may be attributed to two opposing conceptions. The first is the notion of the inherent powers of the courts to entertain any matter brought before them for judicial determination. ${ }^{5}$ The second is the conception that the inherent powers of courts are only meant to complement the powers which the Constitution and statutes confer on the courts, rather than conferring a separate and distinct jurisdiction on them, ${ }^{6}$ as inherent powers do not extend the jurisdiction of courts but merely lubricate it. ${ }^{7}$

Definition of concepts is a problematic academic enterprise, as there is practically no common ground to its conceptualisation. To this end, it is essential to adopt a pragmatic approach in defining any concept. Thus, in Onuoha $v$ Okafor, ${ }^{8}$ the Supreme Court of Nigeria (the Court) laid down two considerations for the determination of what constitutes political question. The first pertains to the lack of satisfactory criteria for judicial determination of the issues before a court, and the second is the appropriateness of attributing finality to the action of the political department under the prevailing constitutional order. ${ }^{9}$ Therefore, the political question doctrine is the notion which assists courts to navigate within the

2 Ibid., 633.

3 P Hogg and A Bushell, 'The Charter Dialogue between Courts and Legislatures: Or Perhaps the Charter of Rights Isn't Such a Bad Thing after All' (1997) 35(1) Osgoode Hall Law Journal 75, 80.

4 Ibid.

5 Constitution of the Federal Republic of Nigeria, Cap C23 Laws of the Federation of Nigeria (LFN) 2004 [hereinafter CFRN 1999 or the Constitution] s 6(6)(a),(b); Adigun v Attorney General, Oyo State [1987] All NLR 328, 344; 2 NWLR (pt 56) 197; see also KM Mowoe, Constitutional Law in Nigeria (Malthouse Press 2008) 179-180.

6 The Young Shall Grow Motors Ltd v Okonkwo [2002] 38 WRN 98.

7 Akilu v Fawehinmi (No 2) [1989] 2 NWLR (pt 102) 122, 197.

8 [1983] NSCC 494.

9 Ibid., 507. 
confines of judicial tradition and by so doing avoid constitutional controversies. This means that in certain situations it will be inappropriate or injudicious for the courts to interfere, overtly or directly, with what properly should be within the realm of the political branches of government. ${ }^{10}$ Thus, a judicial matter contains a political question 'when either the constitution has expressly vested jurisdiction over the issue [in a case] in the other two branches of the government or it is implicit in line with the concept of separation of powers that this should be so.." It should be noted, however, that not all political and constitutional cases constitute political questions, even though all constitutional cases have political relevance. According to Ademola Popoola, political questions are distinguishable from political cases. This is because the characterisation of what constitutes a political question 'does not lie in any possible effect which the decision may have on the political framework of the country'.12

When judicial decisions, in cases involving political questions, produce outcomes which are incongruous with the economic, social or political aspirations of society, such decisions can be considered as having the force of legality but lacking in legitimacy. This means that judicial decisions of courts may be legal (in as much as such decisions are elucidated based on rules that are discernible and implicit or inferred from the legal instrument upon which judicial interpretations are predicated) but lack overt acceptability. This is generally applicable to judicial cases involving political questions. This paper does not seek to critique the decisions of the Court for sake of it, even though it is trite that decisions of courts may be critiqued in appropriate forums such as this, albeit respectfully. In Adigun $v$ Attorney-General, Oyo State, the Court noted that in view of the great powers which the Court wields, it is necessary to exercise such powers with care. Therefore, it is imperative for 'pungent and constructive analytical criticism of every judgement of the Court in the law journals and similar fora. [For] [t]he judgement of a court should not be treated with sacred sanctity, once it gets to the right critical forum'. ${ }^{13}$ This is because the Court is not infallible but merely final. ${ }^{14}$

10 A Casties, 'Justiciability: Political Question' in LA Stein (ed), Locus Standi (Law Books Co 1979) 202; see also, RC Chandler, RA Enslen and PG Renstrom, The Constitutional Law Dictionary: Governmental Powers (ABC-Clio Inc 1987) 644.

${ }^{11}$ A Popoola, 'Politics of the Nigerian Judiciary' in Proceedings of the Nigerian Association of Law Teachers Conference, 1994, 70; see also Chandler, Enslen, and Renstrom, ibid.

${ }^{12}$ Ibid.

${ }^{13}$ Adigun (n 7) 328, 344; 2 NWLR 214-215 (Eso JSC).

${ }^{14}$ Adegoke Motors v Adesanya [1989] 3 NWLR (pt 109) 250, 274-275. 


\section{THE NIGERIAN SUPREME COURT AND THE POLITICAL QUESTION DOCTRINE}

Accordingly, this paper examines the attitude of the Court towards the political question doctrine and highlights the inconsistencies in the approach of the Court in some landmark cases which involved political questions. These inconsistencies undoubtedly constitute a major source of the legitimacy question with regards to the activity of judicial review in Nigeria. ${ }^{15}$ The paper asserts that the decisions of the Court, in cases involving political questions, have been shaped by (i) its deference to the political branches; (ii) the necessity or exigency of the moment; and (iii) the doctrine of avoidance. These factors are suggestive of the Court's 'awareness of the events around [it] and the prevailing social and even political situations. ${ }^{16}$ Certainly, the making of decisions based on the prevailing social and political situations set up the Court as a participant in the policy-making process and by implication a political institution, just as it is also a legal institution. ${ }^{17}$

\section{THE COURT AND CONSTITUTIONAL ADJUDICATION}

The Court is established in section 230 of the CFRN 1999. It is the highest court in the hierarchy of the judicature in Nigeria. All adjudications, with the exception of certain electoral cases, ${ }^{18}$ terminate at the Court. ${ }^{19}$ Apart from the general powers of the Court under section 6 of the CFRN 1999, the Court possesses both original $^{20}$ and appellate ${ }^{21}$ jurisdictions. Cases go on appeal to the Court either as of right ${ }^{22}$ or with leave of the Court of Appeal, which decision is to be appealed, or with leave of the Court. ${ }^{23}$

15 E Nwauche, 'Is the End Near for the Political Question Doctrine in Nigeria?' in C Fombad and C Murray (eds), Fostering Constitutionalism in Africa (Pretoria, University of Pretoria Press 2010) 33; M Ikhariale, 'Impeachment Proceedings and the Political Question Doctrine: The Nigerian Experience' (1990) LASU Law Journal 45, 54.

16 Popoola (n 13) 68.

17 Ibid., 62, 64-65.

18 CFRN 1999, s 246(3); Abubakarv Usman [2017] 15 NWLR (pt 1587) 36.

19 CFRN 1999, s 235. There is, however, a proposal which was sponsored by the Judiciary, seeking to limit the jurisdiction of the Supreme Court of Nigeria in terms of appeals from the Court of Appeal to entertain only cases involving the death penalty, enforcement of human rights and interpretation of the Constitution. See, Policy and Legal Advocacy Centre, 'Factsheet on Bills Seeking to Further Amend the Constitution to Reflect Proposals Initiated by the Judiciary' (July 2017) Issue 3 Factsheet: Review of Relevant Information on Nigeria's Democracy 1.

20 CFRN 1999, s 232; see also, Supreme Court Act Cap S15 LFN 2004, s 17.

${ }^{21}$ CFRN 1999, s 233(1); Supreme Court Act Cap S15 LFN 2004, s 16(1).

22 CFRN 1999, s 233(2).

23 Ibid., s 235(3). 
In terms of the original jurisdiction of the Court, section 232(1) of the CFRN 1999 empowers the Court, to the exclusion of any other court, to entertain cases involving 'any dispute between the federation and a state or between states if and in so far as that dispute involves any question (whether of law or fact) on which the existence or extent of a legal right depends'. The Court is sometimes invited to decide cases which involve political questions that may emanate by virtue of the horizontal relations between the other two branches of government, or from the vertical relations between the federal and state governments, or from electoral, political party and other political activities.

Drawing from the above, the issue whether the Court can competently exercise its judicial powers in such a manner that limits or is capable of limiting the potency of positive law may be raised. ${ }^{24}$ Generally, courts cannot exercise judicial powers to defeat the intention of the legislature or write into legislation what was not intended by the legislature or to rewrite a legislation through judicial decisions. By virtue of the foregoing, the Court is not required to legislate from the bench - not even under the pretext of constitutional adjudication - as to do so would amount to exceeding its judicial powers and venturing into the realm of politics.

\section{What Does Constitutional Adjudication Entail?}

Constitutional adjudication entails judicial interpretation of the constitution. This is because written constitutions are not self-actualising and are inherently indeterminate. ${ }^{25}$ For this reason, written constitutions require interpretation and adaptation to changing circumstances, ${ }^{26}$ which are themselves 'both unavoidable and problematic'. ${ }^{27}$ Even so, James Madison hoped that in a constitutional democracy '[a]mbition must be made to counteract ambition', ${ }^{28}$ so that the law of the constitution could be made self-enforcing by aligning the interests of the departments of government with constitutional rights. ${ }^{29}$ According to Madison's theory, self-enforcement of constitutional law is realisable through constitutional separation of powers between the legislative, executive and judicial branches of

24 Dangana v Usman [2012] 2 SC (pt III) 103, 130.

25 C Lafont, 'Philosophical Foundations of Judicial Review' in D Dyzenhaus and M Thorburn (eds), Philosophical Foundations of Constitutional Law (OUP 2016) 265.

26 D Kommers, 'Germany: Balancing Rights and Duties' in J Goldsworthy (ed), Interpreting Constitutions (OUP 2006) 196.

27 Lafont (n 27).

28 J Madison, 'Federalist 51' in L Goldman (ed), Alexander Hamilton, James Madison, and John Jay: The Federalist Papers (New York, OUP 2008) 257.

29 Ibid. 


\section{THE NIGERIAN SUPREME COURT AND THE POLITICAL QUESTION DOCTRINE}

government. ${ }^{30}$ Therefore, in interpreting the constitution, courts must ensure that the meaning accorded to constitutional texts is true to the spirit of the constitutional order. This is because, first, according to Aharon Barak, a former president of the Supreme Court of Israel, '[e]very [constitutional] text has two meanings: an express meaning and an implied meaning ${ }^{31}$ and second, wide power of construction, in John Taylor's view, may allow courts to stretch constitutional adjudication in manners that render the activity more amenable to the attainment of purposes in view or predetermined objectives just 'as synods do scriptures, according to the temporal interest of the predominant sect'. ${ }^{32}$

The CFRN 1999, like other written constitutions, is open-textured and allows for competing, conservative and liberal readings ${ }^{33}$ of the constitutional texts, and also commits to certain basic constitutional principles. ${ }^{34}$ As already noted, the open-textured nature of Nigerian Constitutions, including the CFRN 1999, gives rise to divergence in constitutional interpretation. While constitutional adjudication may be considered an inevitable and overlapping judicial activity, it is however important to ensure that decisions which emanate from the process are objective and based on positive law, as well as capable of promoting the economic, social and political aspirations of the society. This ensures that judicial decisions produce the best interpretation possible. ${ }^{35}$

It would appear the Court favours two main approaches in constitutional interpretation. The first is the minimalist approach. This approach in the interpretation of the constitution, to a large extent, has its origin in Nigeria's colonial heritage. ${ }^{36}$ The Court applied the minimalist approach, for example, in Attorney-General, Ondo v Attorney-General, Federation (ICPC case), ${ }^{37}$ wherein the Court unequivocally pronounced its support for the anti-corruption policy of

30 J Goldsmith and D Levinson, 'Law for States: International Law, Constitutional Law, Public Law’ (May 2009) 122(7) Harvard Law Review 1792, 1832.

31 A Barak, 'On Constitutional Implications and Constitutional Structure' in D Dyzenhaus and M Thorburn (eds), Philosophical Foundations of Constitutional Law (OUP 2016) 53.

32 J Taylor, Construction Construed and Constitutions Vindicated (Reprint edn, The Lawbook Exchange Ltd 1998) 23.

33 T Roux, 'Transformative Constitutionalism and the Best Interpretation of the South African Constitution: Distinction without a Difference' (2009) 2 Stell LR 278.

34 E Solomon, 'The Basic Structure Doctrine and Implied Limitations on the Exercise of Legislative Powers under the Nigerian Constitution' (2016) 9 University of Uyo Law Journal 267.

35 Ibid., 279-280.

${ }^{36} \mathrm{H}$ Yusuf, 'The Judiciary and Political Change in Africa: Developing Transitional Jurisprudence in Nigeria' (October 2009) 7(4) ICON 654, 664.

37 [2002] 6 SC (pt I) 1. 
the federal government in spite of the unitary disposition of the Corrupt Practices and Other Related Offences Act ${ }^{38}$ which negates the principle of federalism under the Constitution, even as the Court struck down sections 26(3) and 35 of the ICPC Act for its violation of the fundamental right to liberty. ${ }^{39}$ The minimalist approach, it would appear, accounts for the Court's reluctance to enforce, for example, certain provisions of the Fundamental Objectives and Directive Principles of State Policy provisions of the Constitution, ${ }^{40}$ and holding that the objective to eliminate corruption can be realised through the enactment and enforcement of legislation. ${ }^{41}$

The second approach to constitutional adjudication favoured by the Court is the structural or purposive approach. The purposive approach in the interpretation of the constitution involves the systematic analysis or inquiry into the structure and function or purpose of constitutional rules. It seeks to find guidance in constitutional history and the spirit of the constitution as a living document. This approach emphasises practicality over abstract analysis, structure over procedural considerations, efficiency over textuality and the end prevailing over the means. ${ }^{42}$ The structural or purposive approach, therefore, ensures the unity and coherence of constitutional order. ${ }^{43}$ This approach seeks to entrench the existing constitutional order by going beyond explicit constitutional provisions to apply norms that may be implied from the constitutional texts. ${ }^{44}$

The Court has applied the structural or purposive approach in plethora of cases. For example, in Bronik Motors Ltd $v$ Wema Bank Ltd ${ }^{45}$ the Court held that a constitution is a living document which requires a purposive interpretation of its provisions in order to promote the objects of its provisions and intention of the

38 No 5 of 2000, repealed by Corrupt Practices and Other Related Offences Act (No 6 of 2003) Cap C31 LFN 2004 [ICPC Act] s 55.

39 This led to the repeal of the ICPC Act, No 5 of 2000 and the enactment of the ICPC Act, No 6 of 2003.

40 G Okeke and C Okeke, 'The Justiciability of the Non-Justiciable Constitutional Policy of Governance in Nigeria' (January-February 2013) 7(6) Journal of Humanities and Social Science 9-14.

${ }^{41}$ ICPC case (n 39) 28-30.

42 J Madison, 'Federalist 40' in L Goldman (ed), Alexander Hamilton, James Madison, and John Jay: The Federalist Papers (OUP 2008) 194; see also Solomon (n 36).

43 Kommers (n 28) 199-200.

44 C Chandrachud, 'Constitutional Falsehoods: The Fourth Judges Case and the Basic Structure Doctrine in India' in R Albert and B Oder (eds), An Unamendable Constitution? Unamendability in Constitutional Democracies (Springer International Publishing AG 2018) 149; see also Solomon (n 36).

45 [1983] ANLR 272. 


\section{THE NIGERIAN SUPREME COURT AND THE POLITICAL QUESTION DOCTRINE}

framers of the Constitution. ${ }^{46}$ In Dangana $v$ Usman, the Court held that in constitutional adjudication, a judge should not only rely on the constitutional texts but also consider the historical evolution of constitutional practice and history prior to the enactment of the existing Constitution. ${ }^{47}$ In the same vein, in Rabiu v State ${ }^{48}$ the Court held that it is not the duty of the 'Court to construe any of the provisions of the Constitution as to defeat the obvious ends of the Constitution', 49 or indeed to give an interpretation that will defeat the principles upon which a constitutional rule was established. ${ }^{50}$ Also, in Attorney-General, Abia State \& 2 Ors v Attorney-General, Federation (Revenue Monitoring case), ${ }^{51}$ a case in which the plaintiffs challenged the constitutionality of the Local Government Revenue Management Act, a legislation which was enacted to promote the economic and social well-being of the citizens in local communities. In this case, the Court was called upon 'to respond to the dilemma presented by the need to secure a balance between a laudable policy objective with constitutional support and a fundamental black-letter constitutional principle, ${ }^{52}$ In its decision, the Court held that the Revenue Monitoring case was not about the need to curb corruption but about the violation of a major constitutional principle, namely, federalism. ${ }^{53}$

It should be noted however, that there appears to be an emerging approach by the Court in constitutional adjudication. This approach is reflective of the passive disposition on the part of the Court towards constitutional adjudication to the extent of avoiding major constitutional questions brought before it for judicial determination. ${ }^{54}$ The following sections of this paper examine the attitude of the Court in the constitutional adjudication of cases with political questions.

46 Ibid., 291-292.

47 Dangana (n 26) 152.

48 [1980] 8-11 SC 130.

49 Ibid., 149 (Udoma JSC).

50 Attorney-General, Bendel State v Attorney-General, Federation \& 22 Ors [1981] ANLR 85, 130-131.

51 [2006] 2 All NLR 24.

52 Yusuf (n 38) 663.

53 Revenue Monitoring case (n 53) 32.

54 In Attorney-General, Federation v National Assembly [April 2015] Unreported, Suit No SC/214/2015 <http://nationalmirroronline.net/new/fg-drags-nass-to-supreme-court/> accessed 11 January 2018, the Court avoided constitutional adjudication by failing or refusing to determine the constitutionality of the Fourth Alteration Bill 2015 passed by the 7th National Assembly, through the Constitution of the Federal Republic of Nigeria (Fourth Alteration) Bill 2015. Prior to the above case, the Court had avoided the constitutional issues raised in the case brought by the 36 state governments against the federal government of Nigeria over the latter's unilateral operation of the Excess Crude 


\section{THE COURT AND INSTITUTIONAL DEFERENCE}

Institutional deference is a principle in judicial decision making which allows the courts to apply lower level scrutiny in the judicial review process. ${ }^{55}$ This is in contradistinction with the doctrine of separation of powers which ensures that courts 'respect the role of the executive and legislature in formulating policy'. ${ }^{56}$ While the doctrine of institutional deference 'allows for an examination of the reasons which underpin a court's deferential approach in choosing a lower standard of review' ${ }^{57}$ the separation of powers doctrine recognises that the courts have no role in shaping the political process.

In Nigeria, in the period immediately after independence, the judicial attitude of the courts and judges, in cases involving political questions, was highly reflective of the institutional deference principle rather than the separation of powers doctrine. This can largely be attributed to the colonial heritage of the Nigerian judiciary, which accepted the preeminent role of the political branches in the political process. Therefore, in the interpretation of the Constitution and statutes, the Court mostly shied away from making decisions that would suggest its participation in the political process under the cover of judicial review. While in some cases, the Court did not openly acknowledge its deference to the political branches, in other cases, however, the Court made it clear that it was unprepared to engage the political questions involved in such cases in deference to the legislative or executive branches.

In Akintola $v$ Aderemi,${ }^{58}$ for example, a case which arose out of a political crisis in the Western Region of Nigeria (as it then was) and which resulted in the removal of the premier by the governor, the Federal Supreme Court held that in a democracy institutions are required to imbue a spirit of tolerance, compromise and restraint. The Court acknowledged that under a parliamentary democracy, which was the system of government practiced in Nigeria at the time, if a premier realised that he and his government no longer commanded the support of a majority in the House of Assembly, the premier ought to resign or call for the dissolution of the Parliament and the conduct of a fresh election. The Court went on to hold that '[i]f a premier were to go on, although he knew that he did not

Account (ECA), the withdrawal of USD 1 billion from the ECA and the establishment and funding of the Nigerian Sovereign Wealth Fund (SWF) in 2011.

55 K Mclean, Constitutional Deference, Courts and Socio-Economic Rights in South Africa (Pretoria University Law Press 2009) 61.

56 Ibid., 62.

57 Ibid.

58 [1962] 1 All NLR 442. 


\section{THE NIGERIAN SUPREME COURT AND THE POLITICAL QUESTION DOCTRINE}

command a majority he would be departing from democratic principle of majority rule which pervades the Constitution', and such a situation would demonstrate nonconformity with public opinion, as well as the ideals contemplated by the framers of the Constitution. ${ }^{59}$

Regrettably, despite this clear finding which was based on the existing constitutional order, the Court went on to declare the removal of the premier of the Western Region by the governor null and void on the ground that the governor's acceptance that the premier no longer commanded the majority support in the Western Region House of Assembly was a matter that could only be determined on the floor of the House and not otherwise. It should be observed that the Court, in this case, gave greater credence to procedural value over the substantive legitimising value of the case. It is not surprising that the Court's decision was reversed by the Privy Council which agreed with the legal analysis adopted in the dissenting judgement of FJ Brett, which was based on a strict legal position of the case.

In Williams v Majekodunmi ${ }^{60}$ the attitude of the Federal Supreme Court was based, it would appear, on the Court's deference to the legislative branch, rather than the dictates of the law. In this case, the plaintiff challenged the validity of the state of emergency which was declared in the Western Region of Nigeria pursuant to the Emergency Powers Act of 1961. The Court was, therefore, invited to consider, among other things, whether the Federal Parliament had validly exercised its powers under the 1960 Constitution. In the view of the Court, the existence of a state of public emergency in the country is a political issue and 'a matter within the bounds of Parliament and not one for this court to decide' ${ }^{61}$ According to the Court, 'once that state of emergency is declared[,] it would seem that according to the Constitution, it is the duty of the government to look after the peace and security of the State and it will require a very strong case against it for the court to act'. ${ }^{62}$ The Court therefore declined to determine the constitutionality of the exercise of the emergency powers in deference to Parliament. In a remarkable fashion, instead of inquiring into the validity of the exercise of the power to declare a state of emergency, the Court chose to focus on and address the aftermath (the effect) of the exercise of emergency powers.

Similarly, in Attorney-General, Eastern Nigeria $v$ Attorney-General, Federation, ${ }^{63}$ the Court held that it is essentially a political matter to decide what

\footnotetext{
59 Ibid.

60 [1962] 1 All NLR 324.

61 Ibid., 330.

62 Ibid.

63 [1964] 1 All NLR 224.
} 
margin of error is acceptable in a census. Consequently, the Court held that in the circumstance of the case, it was not competent to adjudicate on the matter ${ }^{64}$ and refused to make the declaration that was sought by the plaintiff, namely to invalidate the results of the census exercise. Also, in Lakanmi v Attorney-General, Western Nigeria, ${ }^{65}$ the Court, in essence, recognised a military government as a constitutional government, inferring that the military take-over of government in January 1966 was a voluntary hand-over of power by the executive branch of the civil government to the military. This appears to have been a pragmatic decision on the part of the Court, considering the despotic nature of many military governments. It is also possible that the Court's decision was a deliberate attempt to defer to the action of the executive to voluntarily effect a change of government by handing over power to the military.

In Awolowo v Shagari, ${ }^{66}$ the Court restated that judges are not required 'to apply their opinions of sound policy so as to modify the plain meaning of statutory words ${ }^{67}$ Therefore, in deference to the framers of section 34A (c)(ii) of Electoral Decree No. 73 of 1977 which came up for interpretation, the Court held that the 'Federal Military Government must be deemed to know that two-thirds of 19 States will be $12^{2 / 3}$ States' ${ }^{68}$ This was in spite of the Court's acceptance that the issue at the core of the case involved the interpretation of law, a function which the Court was required to undertake, as it succinctly noted: 'with the minimum of direction from the legislature as to how it should set about this task'. ${ }^{69}$

In Onuoha $v$ Okafor, ${ }^{70}$ both parties contested for their political party's, nomination for a senatorial seat and the plaintiff was chosen by the party, Nigerian Peoples Party (NPP). The defendant petitioned the party against the plaintiff and a panel set up to consider the petition choose the defendant and dropped the plaintiff based on the petition. The plaintiff instituted a law suit to compel the NPP to nominate and sponsor him for election for the senatorial seat instead of the defendant. In its decision, the Court held that it lacked the jurisdiction to entertain the matter because under the 1979 Constitution, nomination and sponsorship of a candidate is a political matter solely within the discretion of a political party. The Court further held that, under the 1979 Constitution and the Electoral Act, the right to canvass for votes lies with political parties, and implicit in the right to

\footnotetext{
64 Ibid., 231.

65 [1971] All NLR (pt II) 201.

66 [1979] All NLR 120.

67 Ibid., 140 (Simon, LC).

68 Ibid., 141.

69 Ibid., 139 (Fatayi-Williams, CJN).

70 Onuoha v Okafor (n 10).
} 


\section{THE NIGERIAN SUPREME COURT AND THE POLITICAL QUESTION DOCTRINE}

canvass for votes is the right to sponsor or not to sponsor a candidate for election. Thus, the Court refused to confirm the plaintiff (now respondent) as the candidate of the NPP, as to do so would, in the words of the Court, 'instantly project or propel the Court into the area of jurisdiction to run and manage political parties'. ${ }^{71}$ In a rhetorical manner, the Court held:

Can the Court decide which of the two candidates can best represent the political interest of the NPP? In all honesty, [...] the Court will in so doing be deciding a political question which it is ill-fitted to do. ${ }^{72}$

It is surprising that the Court failed to make recourse to a constitutional provision which appears to have contemplated the conferment of unlimited powers on the Court to engage in judicial review of all matters between persons or between government or governmental authority and any person in Nigeria for the determination of any question as to civil rights and obligations. ${ }^{73}$ This constitutional principle was restated in Alegbe $v$ Oloyo ${ }^{74}$ wherein the Court held that, in Nigeria, when a superior court is called upon to interpret or apply any provision of the Constitution or the constitution of any organisation with respect to the civil rights and obligations of its members, the court is not dealing with a political question even if the subject matter of the dispute has political implications, as the court is merely performing its function under the Constitution. ${ }^{75}$

The preceding analysis illustrates the Court's deference to the political departments with regard to cases involving political questions. Although these decisions were legally binding, they appeared to lack the standard of legitimacy required of courts. While legality pertains to validity of the decisions (which is a function of law), legitimacy entails the acceptability of the outcome (which is a function of the conscious or deliberate effort towards the satisfaction of economic, social or political aspiration of society). ${ }^{76}$ This means the fact that a decision of a court is legal does not make it right and acceptable to society. Even so, in all the cases examined above, the legislature did not take steps to reverse, modify or avoid the decisions of the Court. The situation is different under the Fourth

71 Ibid., 501.

72 Ibid.

73 Constitution of the Federal Republic of Nigeria 1979, s 6(6)(b).

74 [1983] NSCC 315.

75 Ibid., 341-342 (Fatayi-Williams, CJN).

76 N Udombana, 'Constitutional Restructuring and Fiscal Federalism' (A paper presented at the Dinner Lecture organised by Godswill Akpabio Law House in collaboration with Akwa Ibom North-West Lawyers' Coalition, Uyo, 23 December 2017) 6. 
Republic, as the National Assembly has used appropriate legislative measures to reverse and avoid decisions of the Court in some cases involving political questions. A case in point is the decision in Attorney-General, Federation $v$ AttorneyGeneral, Abia State \& 35 Ors (Oil Resource Allocation cases) ${ }^{77}$ with respect to the boundaries of the littoral states which was reversed and its effect avoided by the Allocation of Revenue (Abolition of Dichotomy in the Application of the Principle of Derivation) Act, which provides that:

[a]s from the commencement of this Act, the two hundred metre water depth Isobath contiguous to a State of the Federation shall be deemed to be part of that State for the purposes of computing the revenue accruing to the federation account from the State pursuant to the provisions of the Constitution of the Federal Republic of Nigeria, 1999 or any other enactment. ${ }^{78}$

Also, section 141 of the Electoral Act 2010 appears to reverse the outcome in Amaechi $v$ INEC ${ }^{79}$ to the extent that '[a]n election tribunal or court shall not under any circumstances declare any person a winner at an election in which such a person has not fully participated in all the stages of the said election, ${ }^{80}$

\section{THE COURT AND THE NOTION OF NECESSITY}

In Attorney-General Bendel State v Attorney-General, Federation \& 22 Ors, ${ }^{81}$ the Court applied the principle of unlimited powers of judicial review under the 1979 Constitution. In this case, the Court disregarded the provision of section 2 of the Acts Authentication Act which established a presumption of regularity and validity to Acts passed by the National Assembly on the grounds of the existential necessity to protect the Constitution from being derogated ${ }^{82}$ and the need to promote public interest. ${ }^{83}$ The Court distinguished the present case from the Census case, which it believed to be a special case considering the overall powers of the Court under the 1963 Constitution vis-a-vis the 1979 Constitution. ${ }^{84}$

77 (No 1) [2001] All NLR 12; (No 2) [2002] All NLR 72.

78 Cap A27 LFN 2004, s 1(1).

79 [2007] 1 All NLR 354.

${ }^{80}$ No 6 of 2010, s 141 [emphases added].

81 [1981] All NLR 85.

82 Ibid., 110, 133 (Fatayi-Williams, CJN).

${ }^{83}$ Ibid., 136 (Bello, JSC).

${ }^{84}$ Ibid., 149, 155 (Idigbe JSC). 


\section{THE NIGERIAN SUPREME COURT AND THE POLITICAL QUESTION DOCTRINE}

In the Oil Resource Allocation case, the Court demonstrated its unlimited power of judicial review. In response to preliminary objections that the determination of the seaward boundary of a littoral state within Nigeria constituted, among others, a political question which should be determined by the legislature, ${ }^{85}$ the Court held that by the provisions of sections 6(1), (6) and 232(1) of the CFRN 1999, it has jurisdiction to interpret all provisions of the Constitution whether on appeal or in exercise of its original jurisdiction. ${ }^{86}$ However, only one dissenting judgement acknowledged that the case was within the political question doctrine. ${ }^{87}$ And according to an amicus curiae in the case:

[t]he seaward boundary of a littoral state is a matter that has been settled by international law, especially the Geneva Convention on the Territorial Sea 1958, and the Third United Nations Convention on the Law of the Sea, and [therefore] not a matter for determination by municipal courts. ${ }^{88}$

In its decision on 5 April 2002, the Court held that the boundary of the littoral defendant states is the low water mark of the seabed and not the Continental Shelf.

It is important to note that in 2001 when the federal government instituted the law suit, the Allocation of Revenue Decree No. 106 of 1992, which ended the dichotomy between on-shore and off-shore oil mineral for the purpose of sharing oil revenues in Nigeria, was an existing law. ${ }^{89}$ This is because when the CFRN 1999 came into force, the legislation was not repealed. In Ibidapo $v$ Lufthansa Airlines, ${ }^{90}$ the Court held that a law did not cease to have effect and validity as an existing law in Nigeria simply because it was omitted in the course of the compilation of the laws of the federation. Accordingly, it held that where there is intent 'to repeal legislation, this should be expressly so stated as the courts generally lean against implying the repeal of an existing legislation unless there exist clear proof to the contrary'. ${ }^{91}$ The implication is that an omission of a law or the presumption of repeal of a law is not tantamount to its repeal. As such, an omitted law or a law presumed to have been repealed

\footnotetext{
85 Oil Resource Allocation case (No 1) (n 79) 137-138.

86 Ibid., 134, 141 (Uwais, CJN).

87 Ibid., 174, 192-193 (Karibi-Whyte, JSC).

${ }^{88}$ E Osieke, 'Case between the Federal Government and 36 States on the Issue of Derivation - Suit No SC/28/2001' (Amicus Curiae Comments) 4.

89 CFRN 1999, s 315(1)(a),(b).

90 [1997-98] All NLR 88.

91 Ibid., 123 (Iguh, JSC).
} 


\section{THE DENNING LAW JOURNAL}

when in fact it was not, would continue to have the same force of validity and applicability as if it had not been omitted or presumed to have been repealed. ${ }^{92}$

Therefore, it is curious that the Court entertained the case in the first place when it was obvious that it would be impolitic or inexpedient to do so, ${ }^{93}$ even to the extent of relying on the colonial Orders-in-Council, common law principles, as well as foreign cases in order to determine the boundary of the littoral states, whereas both the 1960 and 1963 Constitutions had provisions which deemed the Continental Shelf as the boundary of the Southern Regions for the purpose of revenue allocation. ${ }^{94}$ It is submitted that besides involving a political question, the case was hypothetical in nature ${ }^{95}$ and akin to asking the Court for its advisory opinion - a practice that is not known to Nigerian law. ${ }^{96}$ It is further submitted that the Court should have relied on the provisions of sections 134(6) and 140(6) of the 1960 and 1963 Constitutions, respectively. This is because both Constitutions contain express provisions which deem the Continental Shelf as boundary of Southern Nigeria for the purpose of revenue allocation and the definition of the seaward boundary of the littoral states had, at the time, not been expressly or impliedly repealed by the 1979 and 1999 Constitutions which make no reference to the issue.

It is instructive to note that in Garnett $v$ Bradley, ${ }^{97}$ the House of Lords stated an important rule of common sense which suggests that when a new enactment is couched in a manner that the previous law can well stand with it because there is nothing to suggest that the old law has been repealed, and there is no necessity to indicate a contradiction between the two enactments, the old law should remain valid. ${ }^{98}$ With great respect to the Court, it should not have entertained the case or in the alternative, it should have applied this rule of common sense. For, the true test of the rule is in the 'just application of its conformity to" 99 the social reality rather than yield to the political necessity to restate the federal government's dominant position in Nigeria's federal practice using comparative

\footnotetext{
92 Revised Edition (Laws of the Federation of Nigeria) Act 2007, s 2.

93 Nwauche (n 17) 59.

94 It should be noted littoral states are bona fide successors in title to the former southern regions of Nigeria.

95 Saliu v State [1984] 10 SC 104, 113; Awoshima v State [2011] 6-7 SC (pt III) 1, 38.

96 Osieke (n 90) 3.

97 [1878] 3 AC 944.

98 Ibid., 966 (Lord Blackburn).

99 A Hamilton, 'The Federalist 83' in L Goldman (ed), Alexander Hamilton, James Madison, and John Jay: The Federalist Papers (New York, OUP 2008) 406.
} 
constitutional analysis. ${ }^{100}$ The implication of the principle in Garnett with respect to the Oil Resource Allocation case, is that in so far as the definition of the seaward boundary of Southern Nigeria (as it then was) under the 1960 and 1963 Constitutions is not expressly or impliedly repealed by the CFRN 1999, and there is no provision in the CFRN 1999 on the boundary of the littoral states which conflicts with the definition of the seaward boundary of the former southern regions of Nigeria under the 1960 and 1963 Constitutions, the provisions in the latter Constitutions remain valid and applicable for determining the boundary of the littoral states for the purpose of calculating the amount of revenue accruing to the federation account from oil derived from off-shore in favour of the littoral states. ${ }^{101}$

The Amaechi case is another good example of the Court's inconsistency towards the political question doctrine. The facts of the case are that Rotimi Amaechi contested the primary election of the Peoples Democratic Party (PDP) for nomination as the governorship candidate of the party and scored the highest votes. The PDP (third respondent) thereafter substituted him for Celestine Omehia (second respondent) who did not participate in the nomination process. Consequently, Amaechi instituted a law suit at the Federal High Court, Abuja against the Independent National Electoral Commission (INEC) (first respondent), Omehia and the PDP. Amaechi lost at both the court of first instance and the Court of Appeal, hence his further appeal to the Court. It should be noted that the facts in the Amaechi case are similar to those in the Onuoha case. In its decision, the Court set aside the substitution of Amaechi by the PDP on the ground that it was illegal, as no 'cogent and verifiable reasons' were given as required under the Electoral Act 2006. ${ }^{102}$ In Onuoha, the Court decided that it was impolitic and inexpedient to take jurisdiction because it felt that the exercise of judicial power was inappropriate, but in Ameachi the Court not only exercised its power of judicial review, it ordered Omehia to vacate the office of Governor of Rivers State and in its consequential orders directed that Amaechi be sworn in as the Governor on the ground that he was deemed to have won the election. This decision

100 B Silverman, 'The Legitimacy of Comparative Constitutional Law: A Modal Evaluation' (2016) 24(2) Michigan State International Law Review 315-345, 353-354.

101 E Egede, 'Who Owns the Nigerian Offshore Seabed: Federal or States? An Examination of Attorney General of Federation v Attorney General of Abia State \& 35 Ors Case' (2005) 49(1) Journal of African Law 75, 86.

102 Electoral Act 2006, Cap E6 LFN 2004, s 34(2). 


\section{THE DENNING LAW JOURNAL}

understandably attracted serious criticisms by lawyers and non-lawyers alike. ${ }^{103}$ In justifying the Court's meddling in an issue involving a political question, the Court noted that since:

the name of Amaechi was not substituted as provided by law, the consequence is that he was the candidate of the PDP for whom the party campaigned in the April 2007 elections not Omehia and since PDP was declared to have won the said elections, Amaechi must be deemed the candidate that won the election for the PDP. 104

A justification such as the one given above was obviously problematic. It undoubtedly reinforces the view that hard cases make bad law which is bound to leave 'a sour taste in the mouth'. ${ }^{105}$ Thus, to arrive at its decision, the Court chose to amplify the constitutional issue of the fundamental right of Amaechi, ${ }^{106}$ which, according to the Court, deserves to be determined conclusively and with finality in favour of the appellant. ${ }^{107}$

Equally important is the fact that the Court felt the necessity to send a strong warning to the political class and political parties. According to the Court, ' $[\mathrm{t}] \mathrm{he}$ vicious acts of the dramatis personae in this case that have led to this unfortunate and time-wasting court case must not be allowed to repeat themselves. No decent and polished characters can be credited with such vicious acts'. ${ }^{108}$ Instructively, the decision of the Court suggests a response necessitated by a growing and widespread impunity in the PDP, as was evident in other cases previously adjudicated by the Court. ${ }^{109}$

103 F Falana, 'The Rule of Law or the Rule of the Law: Epoch Decisions of the Supreme Court of Nigeria under Review' (Being a paper presented at the Annual General Conference of the Nigerian Bar Association, International Conference Centre, Abuja, 27 August 2008) 8.

104 Amaechi (n 81) 408 (Oguntade, JSC).

105 Ibid., 517 [i] (Aderemi, JSC).

106 Ibid., 395 [h]-[i].

107 Ibid., 399 [g]-[i]; Ibid., 517 [d]-[f].

108 Ibid., 521[f]-[g] (Aderemi, JSC).

109 Ugwu v Ararume [2007] 12 NWLR (pt 1048) 367; Inakoju v Adeleke [2007] All NLR 65. This also appears to have necessitated the decision of the Court in All Progressive Congress v Marafa \& Ors (Unreported SC/377/2019, delivered on 24 May 2019) which renders the victory of all the candidates of the APC party in the 2019 general election in Zamfara State a nullity. 


\section{THE COURT AND AVOIDANCE OF CONSTITUTIONAL ADJUDICATION}

When courts decline jurisdiction to entertain constitutional questions brought for their determination, a major reason for their action is that such issues are within the realm of the political branches. However, this approach is sometimes founded on the notion of constitutional avoidance. ${ }^{110}$ The notion of constitutional avoidance seeks to prevent the courts from becoming entangled in unnecessary controversies, which may arise in the exercise of their power of judicial review, over constitutional issues involving political questions. For this to be possible, courts are advised to acquire passive virtues and be inclined to return constitutional problems involving political questions to the political realm for resolution. ${ }^{111}$ However, it may be argued that by avoiding constitutional problems with political questions and remaining passive, courts might be abdicating their role of judicial review and that the notion of constitutional avoidance, in its original conception, was to be applied only to minor constitutional problems. ${ }^{112}$

In Nigeria, the Court under review has avoided major constitutional cases with political questions on two instances. First, the Court avoided to adjudicate on constitutional disputes instituted by the 36 state governments against the federal government in 2008 and 2011 over the latter's unilateral operation of the Excess Crude Account (ECA) and alleged illegal withdrawal of USD 1 billion from the ECA to fund the Nigerian Sovereign Wealth Fund (SWF) respectively, in breach of the provision of section 162(3) of the CFRN 1999. In spite of the legal controversy surrounding the federal government's operation of the ECA (an important constitutional issue), the Court has not deemed it necessary to make a judicial decision on the cases before it. ${ }^{113}$ Secondly, in Attorney-General, Federation v National Assembly (Constitution Amendment case), ${ }^{114}$ which pertained to the

${ }^{110}$ L Kloppenberg, 'Avoiding Constitutional Questions' (1994) 35(5) Boston College Law Review 1003.

111 A Bickel, The Least Dangerous Branch: The Supreme Court at the Bar of Politics ( $2^{\text {nd }}$ edn, Yale University Press 1986) ch 4.

112 Kloppenberg (n 112) 1016-1017.

113 The federal government's decision, in April 2018, to withdraw another USD 1 billion for the purchase of military hard wares sparked off another round of controversy as to the constitutionality of maintaining the ECA. In fact, this issue has further raised the question of how funds in the ECA should be appropriated. See O Ogunmade and D Oyedele, 'After Senate Rumble, Presidency Says Buhari Yet to Authorise \$1bn Withdrawal from ECA' This Day (Lagos, 10 April 2018) 1, 6.

114 [April 2015] Unreported, Suit No SC/214/2015. 
constitutional issue of constitutional alteration or amendment, the federal government sued the National Assembly for, as it claimed, unconstitutionally amending the Constitution pursuant to the latter's powers in section 9(1) \& (2) of the CFRN 1999. The alteration or amendment sought to, among other things, (i) alter the constitutional practice of presidential assent to Bills passed by the National Assembly in respect of alteration or amendment to the Constitution, ${ }^{115}$ (ii) alter the extent of presidential power in respect of assent of ordinary Bills, ${ }^{116}$ and (iii) alter executive powers of the president to appoint persons to certain public offices established under the CFRN 1999. ${ }^{117}$ The Court avoided to adjudicate on the disputed constitutional amendment Fourth Alteration Bill 2015, and instead returned the case to the legislative and executive branches for political resolution of the issues raised in the case. It merely observed that it is the president, and not the attorney-general, who ought to have been the plaintiff in the suit because he decided to exercise his constitutional power not to assent to the Bill. ${ }^{118}$

\section{APEX COURTS AND POLITICAL QUESTION: A COMPARATIVE REFLECTION}

There appears to be a consensus on the notion that courts are guardians of any genuine democratic enterprise. ${ }^{119}$ The only point of divergence, it would seem, is the extent of the courts' guardianship of constitutional democracy, in view of the fact that legislative and constitutional provisions which empower the courts in this regard range 'from the relatively specific to the extremely open-textured'. ${ }^{120}$ This situation creates room for contending models on how courts in a constitutional democracy should deal with political questions. According to John Ely, this is the basis for the debate between the proponents of interpretivist and non-interpretivist models. ${ }^{121}$ While the former holds that courts deciding constitutional issues should confine themselves to enforcing norms that are stated or clearly implicit in the constitution, the latter is of the notion that courts should go beyond the provisions

\footnotetext{
115 Constitution of the Federal Republic of Nigeria (Fourth Alteration) Bill 2015, s 4, which sought to amend s 9 of the CFRN 1999 by adding a new ss 3A to s 9.

116 Ibid., s 14, which sought to amend s 58 of the CFRN 1999 by adding a new ss 5A to s 58 .

117 Ibid., s 23, which sought to amend the CFRN 1999 by adding new s 84A-84F.

118 Solomon (n 36) 267-268.

119 J Ely, Democracy and Distrust: A Theory of Judicial Review (Harvard University Press 1980) 73.

120 Ibid., 13.

121 Ibid., 1.
} 


\section{THE NIGERIAN SUPREME COURT AND THE POLITICAL QUESTION DOCTRINE}

of the constitution to make judicial pronouncements on norms that cannot be discovered within the confines of the legal document under review. ${ }^{122}$ This leaves constitutional theorists in a quagmire, as the former approach is characterised by analyses that are incapable of keeping faith with the spirit of written constitutions, while the latter approach simply ends up constituting constitutional courts as legislative bodies. ${ }^{123}$ Interestingly, both conceptions appear to have left out in their arguments the interests of the parties (which are in some cases the citizens) whose expectations trigger the process of judicial review. This requires a broadened perspective which makes it imperative to establish a balance among the different branches of government. ${ }^{124}$ Therefore, when evaluating the legitimacy of the approach adopted by courts to political questions, it seems important to also consider the rationale and the justification for the action as understood by parties who are supposed to benefit from the outcome.

Yet, as earlier noted, in a constitutional democracy, the normative political view is that elected officials are solely responsible for issues constitutionally assigned to the political department. However, the crucial role of the courts in shaping such issues is undeniable (especially the apex courts, irrespective of the nomenclatures that are used to describe them). ${ }^{125}$ This practice has given rise to what has been described as the counter-majoritarian difficulty. ${ }^{126}$ In response, it has been argued that the notion of counter-majoritarian difficulty is an exaggeration, because courts' participation in the policy-making process is quite negligible. ${ }^{127} \mathrm{In}$ Germany, for example, where there exists a purely political mechanism in the selection of the justices of the Federal Constitutional Court, ${ }^{128}$ there is acceptance that the German Basic Law (Grundgesetz) is the interpretation given by the Federal Constitutional Court. ${ }^{129}$ In this regard, Donald Kommers asserts that:

[m]ost scholars and legal professionals accept the Court as a legitimate participant in the larger community decision-making process, [for which]

\footnotetext{
122 Ibid.; see also Barak (n 33) 56-62.

123 Ibid., 73.

124 Lafont (n 27) 268.

125 M Bckenforde and others, Judicial Review Systems in West Africa: A Comparative Analysis (International Institute for Democracy and Electoral Assistance and Hanns Siedel Foundation 2016) 20-21.

126 Bickel (n 113) 16-17.

127 A Vermeule, 'System Effects and the Constitution' (November 2009) 123(1) Harvard Law Review 6, 38.

128 Kommers (n 28) 173.

129 Ibid., 212 (citing Smend).
} 


\section{THE DENNING LAW JOURNAL}

Germans realise that the Court walks a tight rope between law and politics, and the justices themselves are acutely aware of their political influence. ${ }^{130}$

This practice explains why a former president of the German Federal Constitutional Court noted that:

[i]ntellectual honesty compels us to state that there is no usable catalogue of criteria that could serve as signpost in the ridge-walking between law and politics. The two fields of action partly overlap, and cannot unambiguously be separated from each other. As the constitutional review body, the Court has a share in politics. ${ }^{131}$

The above practice is also applicable in India where the Supreme Court is acknowledged as a political institution, ${ }^{132}$ and its engagement in 'astute political craftsmanship' is very well reckoned with. ${ }^{133}$ The same might be said of the South African Constitutional Court, which origin is rooted in post-apartheid politics, with its mode of selection of its justices akin to the practice in Germany. ${ }^{134}$ The US Supreme Court has equally been described as a judicial institution with a mixture of political and policy-making functions. ${ }^{135}$

In Nigeria, by virtue of the structure of the Constitution (with the separation of governmental powers as one of its core principles), it would appear the Court is not empowered to attribute finality to a legitimate action or inaction which belongs in the political realm, as the mechanism for constituting the Court makes it incapable of proffering enduring answers to political questions. Also, the Court lacks the experience and facility to engage in the function of legislating. Yet, it is practically impossible for the Court to be completely insulated from such activity because of its role as guardian of the Constitution. ${ }^{136}$

130 Kommers (n 28) 212-213.

131 J Limbach, 'The Law-Making Power of the Legislature and the Judicial Review' in B Markesinis (ed), Law Making, Law Finding and Law Shaping: The Diverse Influences (OUP 1997) 174.

132 S Sathe, 'India: From Positivism to Structuralism' in J Goldsworthy (ed), Interpreting Constitutions: A Comparative Study (OUP 2006) 261-263.

133 Chandrachud (n 46) 152.

134 H Klug, 'South Africa: From Constitutional Promise to Social Transformation' in J Goldsworthy (ed), Interpreting Constitutions: A Comparative Study (OUP 2006) 282-285.

135 R McCloskey, The American Supreme Court (University of Chicago Press 1960) 20.

136 A Nnamani, 'The Judiciary in the 1990s: Expectation and Challenges' (1990) 1(3) Justice: A Journal of Contemporary Legal Problems 27. 


\section{CONCLUDING REMARKS}

From the analysis thus far, it has been shown that the Supreme Court of Nigeria exercises considerable power and control over issues which ordinarily belong in the political department, in the course of defining the legal rights and obligations of parties before it. In Inakoju v Adeleke, ${ }^{137}$ the Court was of the view that " $[\mathrm{t}] \mathrm{he}$ political question doctrine is still in its embryonic stage in Nigeria. Let us not push it too had to avoid the possibility of a still-birth. That will be bad both for Nigerian litigants and the legal system.' ${ }^{138}$ Perhaps, this explains the Court's restraint in some cases and why it ignores the age-long norm that courts should not legislate from the bench in others. By not exercising judicial self-restraint in matters which involve political questions, the Court follows in the path of its counterparts in other jurisdictions such as Germany, India, South Africa and the United States in walking a thin line between law and politics. More so, by entering the unfamiliar political department, the Court is more likely to over step the bounds of its judicial powers.

There is also a tendency for the Court to arm itself with the arguments that the cases brought before it involve questions of law and facts; ${ }^{139}$ that the political question doctrine does not justify the total and absolute preclusion of judicial review, as it would be resisted as a basis of lack of judicial review; ${ }^{140}$ and that there is a distinction between the process of adjudication, which is a non-political activity, and the effects of its decisions, which may sometimes be regarded as political. ${ }^{141}$ While adjudication is about finding the law, politics is, by contrast, an activity which involves making the law. ${ }^{142}$ However, because 'constitutional adjudication [is] an inevitable political practice everywhere it occurs, there is one thing and one thing only that conscientious judges should do, and that is to openly declare the politicality of their decision-making practices. ${ }^{143}$ In Nigeria, this has become imperative in view of the notion that under the exiting constitutional order the Court is deliberately meant and made to be a super Court to the extent of its decisions, ${ }^{144}$ especially in the context where cases involving political questions constitute veritable and potential land mines. This is because, in Nigeria, politics

\footnotetext{
137 [2007] All NLR 65.

138 Ibid., 85, 117 (Tobi, JSC).

139 Oil Resource Allocation case (No 1) (n 79) 147.

140 Inakoju (n 111) 179, 183 (Musdapher, JSC).

141 Kommers (n 28) 213.

142 Limbach (n 133) 161.

143 Roux (n 35) 279.

144 Adigun (n 7) 344.
} 
appears not to be a tool for nation building and is yet to develop beyond the struggle by political actors to acquire political and economic power for self-aggrandisement. This is evident in the rampaging political arrogance ${ }^{145}$ that may not be unconnected with the cultural factor which conceives power 'as being personal, permanent, mystical and pervasive'. ${ }^{146}$ To this end, in cases involving political questions, the Court must aim at making decisions which represent reasoned agreement in society. ${ }^{147}$ Otherwise, such decisions should be reversed, modified or avoided by a new law.

145 W Soyinka, Interventions (vol 1, Bookcraft 2010) 239; C Achebe, The Trouble with Nigeria (Heinemann Educational Publishers) 9.

146 B Nwabueze, Constitutional Democracy in Africa: Constitutionalism, Authoritarianism and Statism (Spectrum Books) 272-273.

147 Tremblay (n 3) 632. 